Журнал«Герспективита інновації науки

(Серія«Гердагогіка», Серія «Гицхологія», Серія«Медицин»

№4(4) 2021

УДК 378.147

https://doi.org/10.52058/2786-4952 -2021-4(4)-246-255

Осаульчик Ольга Борисівна кандидат педагогічних наук, доцент, викладач кафедри іноземної філології та перекладу, Вінницький торговельно-економічний інституту КНТЕУ, вул. Соборна, 87, м. Вінниця, 21050, тел.: (067) 215-15-68, e-mail: aulolga55@gmail.com, https://orcid.org/0000-0003-4933-0652

\title{
ВИХОВНИЙ ПОТЕНЦІАЛ ОСВІТИ В УМОВАХ ДИСТАНЦІЙНОЇ ФОРМИ НАВЧАННЯ У ВИЩІЙ ШКОЛІ
}

Анотація. Стаття присвячена проблемі виховного впливу дистанційно організованого навчання у вищій школі. Наукові дослідження останніх років засвідчили відсутність розробленої конкретної технології і методики виховання молоді в умовах дистанційного надання послуг. Поруч із тим, дистанційна освіта $€$ невід'ємною частиною освітнього процесу сьогодні, відтак відсутність напрацювань іiі виховного потенціалу $є$ нагальною і важливою педагогічною проблемою ії менеджменту. В межах нашого дослідження було проаналізовано етапи оновлення традиційної форми освіти 3 iї змінними виховними пріоритетами, а також розвиток дистанційної форми освіти. Охарактеризовано сучасний етап, як етап повномасштабного впровадження дистанційної освіти, 3 відповідними ознаками (мінімізовані й опосередковані функції педагоганаставника, більший ступінь самоорганізації студентів, важливість їхньої самомотивації та раціонального таймменеджменту). Зазначені ознаки визначено такими, що мають виховний потенціал у вищій школі, тому було висвітлено ряд методик ефективного таймменеджменту в організації самостійної роботи студентів. В процесі дослідження було акцентовано увагу на тому, що система виховного впливу в умовах дистанційного навчання не $\epsilon$ розробленою i впровадженою, відтак $є$ перспективою подальших розвідок і напрацювань. Разом із тим було наголошено, що в створенні такої системи мають враховуватися як основоположні принципи виховної роботи у вищому навчальному закладі, так i специфічні умови дистанційного організованого навчального процесу. 3 огляду на зазначене, було узагальнено основоположні виховні ідеї вищої школи на сучасному етапі й можливість їхньої реалізації в дистанційно організованому навчальному процесі. За результатами нашого дослідження умови дистанційної освіти сучасної вищої школи повністю відповідають інтенсифікації методів самоосвіти та самостійної роботи. Визначено, що сучасні освітні платформи у цікавому форматі та у формі гейміфікованих завдань здатні сформувати мотиваційну складову й самомотивацію студентів у подальшому, в той час як останнє є рушійною силою раціонального таймменеджменту. Доведено, що дистанційна освіта сприяє розвитку творчого потенціалу студентів за допомогою 
підбору відповідних навчальних завдань: створення інтелект-карт, робота над індивідуальними і груповими проектами, презентаціями, колажами, вирішення відкритих проблемних питань тощо. Як результат, нами було виокремлено відповідні рівні виховного потенціалу дистанційної освіти: мотиваційний, інформаційно-пошуковий, організаційний, креативний та рівень самоосвіти.

Ключові слова: дистанційна освіта, виховний потенціал, вища школа, самоосвіта, самостійна робота, таймменеджент.

Osaulchyk Olga Borysivna Candidate of Pedagogical Sciences, Associate Professor, Senior Lecturer at the Department of Foreign Philology and Translation of Vinnytsia Institute of Trade and Economics of Kyiv National University of Trade and Economics, Soborna St., 87, Vinnytsia, 21050, e-mail: aulolga55@gmail.com, https://orcid.org/0000-0003-4933-0652

\section{UPBRINGING POTENTIAL OF HIGHER SCHOOL EDUCATION UNDER THE CONDITIONS OF DISTANCE LEARNING FORM}

Abstract. The article is devoted to the problem of the upbringing impact of distance learning in higher education. Scientific researches of recent years have shown the lack of developed specific technology and methods for students' upbringing within the distance learning. At the same time, distance education is an integral part of the whole educational system today, so the lack in the development of its upbringing potential becomes an urgent and important pedagogical problem of its management. In the framework of our study, the stages of updating the traditional form of education with its variable upbringing priorities, as well as the development of distance education were analyzed. The modern stage is characterized as a stage of full-scale implementation of distance education, with its appropriate features (minimized and indirect functions of the teacher-mentor, a greater degree of self-organization of students, the importance of their self-motivation and rational time management). These features are defined as those having educational potential in higher education, so a number of methods for students' effective time management in the organization of their independent work were also highlighted. In the course of the research it was emphasized that the system of upbringing impact under the conditions of distance learning is not developed and thus not implemented, therefore it is a prospect for further scientific explorations and developments. At the same time, the attention was drawn to the fact that the creation of such a system should take into account both the basic principles of upbringing activity in higher education and the specific conditions of distance learning. In view of the above mentioned, the basic educational ideas of higher education at the present stage and the possibility of their implementation in the distance learning process were generalized. According to the results of our study, the conditions of distance learning in higher education fully correspond to the intensification of self-education and independent work methods. It is determined that 
modern educational platforms in an interesting format and in the form of gamified tasks are able to form the motivational component and self-motivation of students in the future, while the latter is the driving force of rational time management. It is proved as well that distance education promotes the development of creative potential of students through the selection of appropriate learning tasks: the creation of mind maps, work on individual and group projects, presentations, collages, solving open-question problems etc. As a result, we have identified the appropriate levels of the upbringing potential of distance education: motivational, information-searching, organizational, creative and the level of self-education.

Keywords: distance learning, upbringing potential, higher school, self-education, independent work, time management.

Постановка проблеми. Зовнішні фактори, зокрема коронавірусна хвороба, пришвидшили й максимально активізували впровадження дистанційної форми навчання в освітньо-виховний процес. Дистанційне навчання, у свою чергу, дало поштовх інформаційно-цифровим технологіям, включаючи мас-медіа, опиратися на потреби тих, хто навчається, тобто бути переорієнтованими й випускати все більше готової продукції саме в освітній площині. Варто відмітити, що зусилля викладачів, представників мас-медіа та розробників цифрової продукції не були марними й розвиток дистанційної освіти на сьогодні на високому рівні, який дозволяє, за необхідності, повністю змінити очне навчання або реалізувати гібридне навчання. Проблема активного розвитку й успішного впровадження дистанційного навчання й досі перебуває в центрі уваги науковців і дослідників, проте уважного ставлення за визначених умов вимагає виховна сторона освітнього процесу. Так, на сьогодні розвиток дистанційної форми освіти набирає все більших обертів, проте більшість науковців розглядають іiі суто 3 позиції навчальних можливостей, проте не виховних. Таким чином, суттєвим питанням постало здійснення виховної роботи та соціалізації тих, хто навчається, адже якщо в організації та здійсненні навчального процесу вже $\epsilon$ певні напрацювання, то у виховній роботі вони відсутні. На думку I. Найдьонова відсутність розробленої конкретної технології і методики виховання молоді в умовах дистанційного надання послуг $\epsilon$ найважливішою педагогічною проблемою сучасного менеджменту дистанційної освіти [5]. Тому в межах нашого дослідження ми акцентуємо увагу саме на виховних можливостях дистанційно-організованого навчання у вищій школі.

Аналіз останніх досліджень і публікацій. Вивченням питання дистанційної освіти займається багато науковців, серед яких I. Бех, В. Бондаренко, Н. Гаврилюк, Л. Довгань, Н. Іваницька, В. Кухаренко, І. Найдьонов, Г. Пономарьова, Н. Тимощук та інші. Проблематику виховного аспекту у вищій школі в контексті провідних ідей і сучасних пріоритетів вивчали О. Дубасенюк, О. Дурманенко, Р. Сопівник, М. Фіцула, Н. Якса, О. Лялюк та інші. Разом із тим, у своїх дослідженнях дистанційної організації навчального процесу більшість 
дослідників так чи інакше торкалися іiі виховного потенціалу, проте лише частково, тому визначене питання залишається малодослідженим й потребує додаткових роз'яснень і рекомендацій.

Мета статті - дослідження виховного потенціалу дистанційної освіти у вищій школі.

Виклад основного матеріалу. Створення умов для апробації i впровадження дистанційної освіти почалось задовго до карантинних обмежень. Так, першими університетами, які отримали дозвіл МОН Україні на проведення експерименту 3 дистанційного навчання, були Сумський державний університет та Хмельницький національний технічний університет. На жаль, суттєвої активності у цьому процесі в університетах України не спостерігалось [3, С. 8]. На нашу думку, таке ставлення було пов'язане, насамперед, 3 острахом та неготовністю через недостатню обізнаність викладацького складу до кардинального перезавантаження традиційної освітньої системи.

Прослідковуючи шлях змін і оновлень в традиційній освітній системі, за Р. Сопівником можна виділити чотири основних етапи. Так, ще у 1990-му році система освіти базувалася на підходах, спрямованих на формування колективістської свідомості, оскільки загальновизнаним був приорітет загальносуспільного над особистісним, з чого випливало домінування підходу навчання і виховання студентів у колективі. Початок другого етапу відбувся у першій половині 90-х рр., коли головні виховні засади зосереджувалися у площині національних ідеалів і цінностей, а основним завданням вищої школи стало формування гармонійно розвинутої особистості, 3 високим рівнем сформованості національної самосвідомості. Третій етап розпочався 3 другої половини 90-х рр. ХХ ст. до 2002 р., коли внаслідок розвитку і становлення ринкової економіки здобувачі вищої освіти стали більш активними задля здобуття високопрофесійних навичок. В цей період розвиваються різні форми студентського самоврядування, серед методів починає домінувати самостійна робота, самоосвіта та самовиховання у поєднанні 3 активною громадського позицією. Разом із тим, все ще спостерігається домінування директивного стилю в організації й керуванні діяльністю студентів. Нарешті, четвертий етап, визначається як період, коли активно впроваджуються у навчально-виховний процес нові інформаційні технології, відбувається зародження дистанційної освіти, втілюються ідеї Болонського процесу, реалізується кредитно-модульна система навчання, яка у свою чергу стимулює самоосвітню діяльність студентів впродовж усього навчального періоду під педагогічним супроводом викладача. При чому, особливе значення так само, як і в попередньому періоді, відводиться вихованню різнобічно розвинутої особистості, громадянина-патріота, людини здатної до постійної самоосвіти, самоактуалізації, самоменеджменту i самовиховання, озброєної комплексом методів i прийомів умінь i навичок перманентного оновлення знань в умовах швидкоплинних суспільних змін, науково- технічного прогресу [7]. 
Журнал«Герспективита інновації науки

(Серія«Гедагогіка», Серія «Гиихологія», Серія «Медицинв»

№4(4) 2021

В контексті зазначеного вище можемо стверджувати, що 3 моменту повномасштабного впровадження дистанційної освіти розпочався наступний етап у зміні підходів до навчально-виховного процесу вищої школи. Функції педагога-наставника на цьому етапі мінімізовані, адже вони регулюються дистанційно. Дистанційність означає ще більший ступінь самоорганізації студентів, виникають нові дотичні поняття, зокрема самомотивація i таймменеджмент. Зазначені поняття є взаємопов'язаними і взаємозумовленими: саме за наявності певної мети з'являється необхідність правильної організації видів робіт і розподіл часу, тобто таймменеджмент. Управління часом спрямовано на продуктивну організацію робочого часу та дозвілля. Студент в університеті має усвідомлювати необхідність правильного розподілу часу відповідно до особистих інтересів та необхідної роботи [6]. В умовах дистанційного навчання за відсутності очного контролю 3 боку викладача потрібно використовувати час із максимальним виконанням актуальних задач, розділених на проміжні завдання, з маленькими перервами. Саме такий підхід, на думку О. Лялюк не призведе до перевтоми та перенавантаження. Також таймменеджмент включає правильний розподіл часу для відпочинку, здорового харчування здорового сну [4, С.18-25].

В означеному контексті в межах виховної роботи зі студентами, на нашу думку, на початковому етапі доцільно буде ознайомити студентів з основними методиками тайм-менеджменту:

- методика Ейзерхауера полягає в пошуку i правильній розстановці пріоритетів, серед яких можна виділити чотири групи: 1) термінові й першочергові, 2) важливі, проте менш нагальні, 3) термінові, проте менш важливі, 4) менш важливі і менш термінові;

- методика «Альпи» базується на принципі «60:40», де 60\% часу займає виконання щоденних робочих завдань i 40\% часу має бути в резерві для відпочинку. Методика складається складається 3 п'яти етапів: 1) складання списку справ на день; 2) визначення часового проміжки для виконання кожного завдання; 3) планування відпочинку; 4) розстановка пріоритетних завдань; 5) за необхідності, зміни в перенесенні завдань;

- методика Паретто базується на співвідношенні «80:20», де першорерговим є вирішення важливих питань в $20 \%$ часу з результатом у $80 \%$, а другорядними $\epsilon$ менш важливі завдання, які можуть займати до $80 \%$ часу, проте давати лише $20 \%$ результативності;

- методика Франкліна передбачає поділ об'ємних завдань на малі завдання, а останні на ще менші підзавдання. Такий розподіл можна втілити у побудові піраміди, яка включає глобальну мету, поділ на окремі цілі, план досягнення окремих цілей, довгостроковий план, короткостроковий план, план на день;

- методика «Слон» $є$ аналогічною до попередньої і передбачає поділ великої справи на малі частини, з яких легше розпочати і таким чином заглибитись у виконання загального завдання; 
- методика «АБВ», в якій завдання категорії «А» найважливіші і підлягають негайному вирішенню, завдання категорії «Б» можуть бути відкладеними на деякий час, завдання «В» можуть бути вирішеними у будь-який період часу, часто $є$ особистими і не впливають на робочий процес.

- методика «Кошик для сміття» передбачає роботу за чистим столом, коли задля ефективної роботи ми маємо звільнитися від залишків від попередньої роботи (непотрібними паперами, зайвими файлами на робочому столі тощо), оскільки зайве відволікає, заважає процесу зосередження над одними видом роботи, науково доведено, що інколи $30 \%$ часу ми витрачаємо на пошук необхідного документа;

- методика «Як все встигнути» («Getting Things Done») є аналогічною до попередньої і полягає в тому, що необхідно розвантажити голову від зайвої інформації, налаштуватися на виконання конкретного завдання, при чому впорядкування власних паперових і електронних носіїв допомагає в цьому.

Вважаємо, що всі запропоновані методики $є$ раціональними та $є$ результатом досвіду успішних людей. Разом із тим, в ході виконання робочих завдань в кожної людини виробляється власний стиль таймменеджменту, який може відповідати одній із згаданих методик, або бути сумішшю декількох варіантів, або бути новою власною методикою організації i планування часу. Підсумовуючи інформацію про методики таймменеджменту, можемо додати, що завжди варто залишати час на форсмажорні обставини, які можуть виникати непередбачувано й зруйнувати запланований перебіг робочого дня.

На сьогодні більшість тих, хто навчається у вищій школі, готові працювати віддалено і самостійно, психологія студентів почала змінюватися із збільшенням освітніх інформаційних потоків, коли 3'явилася можливість відкритого доступу до знань [9]. Тоді ж і почала змінюватися психологія викладачів: відносини між викладачем і студентами поступово ставали проблемно-консультативними, а монолог зі сторони викладача поступово став перетворюватися на діалог, відбулося збільшення відведених годин на самостійну роботу студентів 3 основним пріоритетом «навчити вчитися». Адже в дорослої людини з часом процес виховання переростає в самовиховання, прагнення до самореалізації, саморозвитку, самовдосконалення.

Такі тенденції стали сприятливим підгрунтям для якісного впровадження дистанційної освіти з урахуванням тих виховних можливостей, які вона може надати.

За визначенням М. Фіцули виховання у вищих навчальних закладах уособлює систему заходів, спрямованих на формування всебічно й гармонійно розвиненої особистості та здійснюється як у процесі навчання, так і в позааудиторний час [8]. Проте, під час дистанційного навчання такий розподіл значно звужується: виховний вплив відбувається лише опосередковано і безпосередньо в процесі занять. Донині система виховного впливу в умовах дистанційного навчання не $\epsilon$ розробленою і впровадженою, проте, цілком 
очевидним є той факт, що в іiі створенні мають враховуватися як основоположні принципи та ідеї виховної роботи у вищому навчальному закладі, так i специфічні умови дистанційного організованого навчального процесу.

Так, у зв'язку з реформуванням вищої школи та інтеграцією вищої освіти в Європейське співтовариство, основна ідея виховної роботи у вищому навчальному закладі полягає у вихованні майбутнього спеціаліста не тільки громадянином своєї країни, а й «громадянином світу». Останнє передбачає виховання особистості в дусі толерантності до інших людей та їх праці, незалежно від їхнього віросповідання, соціального статусу чи етнічної приналежності; поваги до власної країни та інших держав; ціннісного ставлення до природи тощо.

Також в умовах інтеграції вищої освіти в Свропейське співтовариство, у виховній роботі зі студентами має надаватися перевага новим підходам до ії організації, адже потрібен спеціаліст нового формату [2, С. 31-37]. Такий фахівець має бути здатним швидко адаптуватися до різних умов праці та роботи у будь-якому колективі, готовим творчо вирішувати будь-які професійні завдання, це має бути активна i комунікабельна особистість, здатна до постійного самовдосконалення. Тому діяльність педагогів у виховній роботі вищої школи має орієнтуватися на індивідуальну траєкторію розвитку студента 3 приорітетом самостійної роботи. За результатами дослідження О. Дубасенюк, виховна робота у вищому навчальному закладі має бути реалізована на таких рівнях: соцієтарному (суспільному, охоплює вплив на особистість з боку всього суспільства), інституалізованому (адміністративному, на якому виховання здійснюється у межах певного навчально-виховного закладу), інтерперсональному-педагогічному, який характеризується способами індивідуального чи групового виховного впливу на студентів, інтраперсональному-самоуправлінському, на якому здійснюється самовиховання особистості. [1, С. 91]. Проте дистанційне навчання $є$ віддаленим від навчального закладу і педагога, тому не може повноцінно охоплювати всі зазначені рівні. Разом із тим, дистанційна форма освіти має виховний потенціал і певні переваги у виховному аспекті.

Говорячи про умови дистанційної освіти сучасної вищої школи, можемо стверджувати, що вони відповідають інтенсифікації методів самоосвіти та самостійної роботи. Студенти можуть швидко освоїти самодисципліну для досягнення успіху та педагоги можуть помітити недостатню зрілість i самодисципліну у студентів, які не підготовлені до онлайн-навчання [3, С. 20]. При чому розвиток інформаційних технологій та можливостей інтернету, за допомогою яких реалізується та розвивається дистанційна форма освіти, здатні забезпечити ефективність цього процесу, що здійснюється під контролем та на засадах партнерського співробітництва педагогів із студентами. Іншими словами, освітні можливості сучасних інформаційних технологій дозволяють успішно дистанціювати навчальний процес, спрямовуючи його у бік самостійної роботи. 
Сучасні освітні платформи пропонують різні види навчально-пошукової діяльності, як індивідуального, так і групового характеру. Яскравий і цікавий формат, гейміфіковані завдання здатні зацікавити та підвищити самомотивацію студентів щодо вивчення певної дисципліни. У свою чергу, як вже зазначалося вище, самомотивація $\epsilon$ рушійною силою у формуванні навичок таймменеджменту студентів. Поруч із цим, дистанційний формат навчання має достатню базу потужностей для розвитку креативної складової особистості. Так, за допомогою підбору відповідних навчальних завдань (створення інтелект-карт, робота над проектами, презентаціями, колажами, вирішення відкритих проблемних питань тощо) студенти змушені активізуватися у творчо-пошуковій діяльності, що зрештою розвиває креативність і творчий підхід.

Узагальнюючи викладене вище, можемо стверджувати, що виховний потенціал дистанційної освіти може бути реалізованим на наступних рівнях: мотиваційному, інформаційно-пошуковому, організаційному, креативному, самоосвітньому, що представлено нами у рис. 1.:

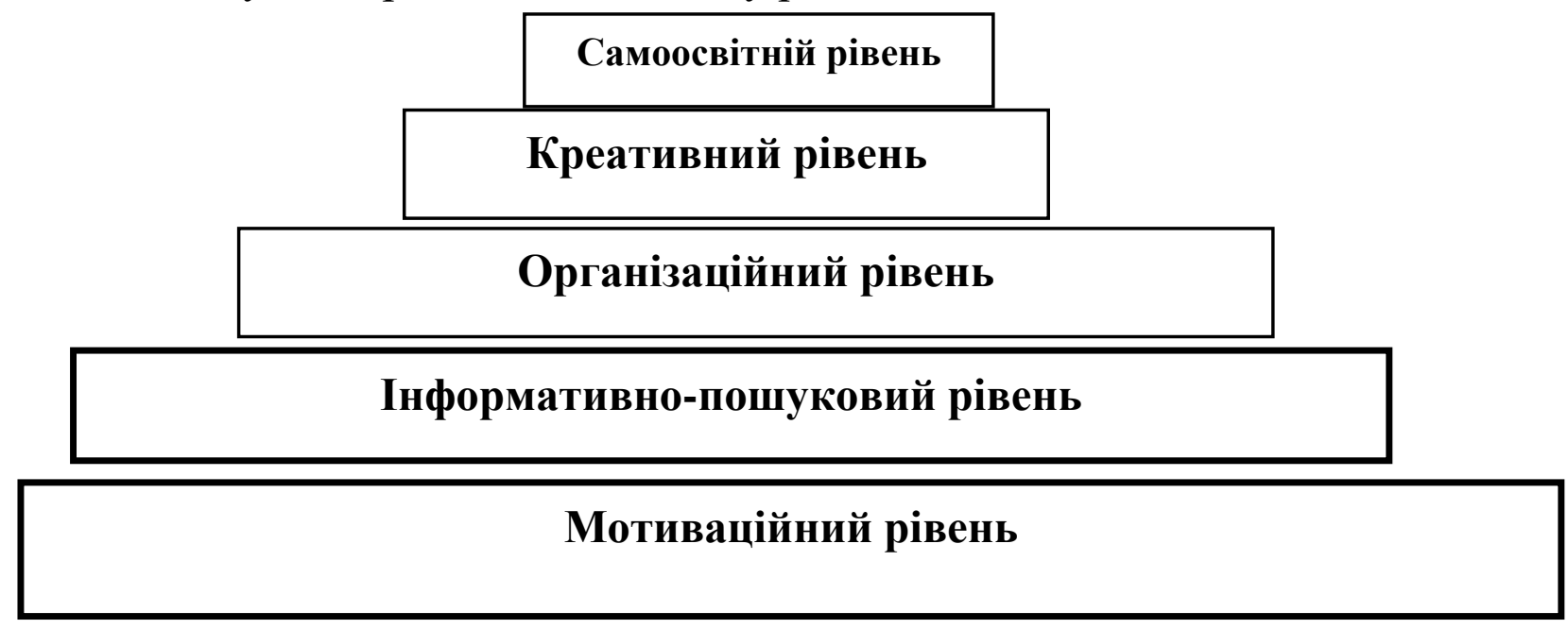

Pис. 1 . Рівні виховного потенціалу дистаниійної освіти

Так, за результатами нашого дослідження в основі виховного потенціалу дистанційної освіти є мотивація студента, що, у свою чергу, дає поштовх його інформаційно-пошуковій діяльності. Наступним рівнем нами визначено організаційний рівень, який уособлює ефективно-побудований таймменеджмент студента. Креативність або творчий потенціал $\epsilon$ наступними виховними досягненнями у умовах дистанційно організованого навчального процесу. Найвищим рівнем, на нашу думку, $є$ виховання самоосвітніх навичок і цінностей студента, що відповідає необхідності «навчити вчитися» та освіті впродовж життя і є домінуючим пріоритетом освіти на сьогодні.

Висновки. Отже, відсутність розробленої конкретної технології і методики виховання молоді в умовах дистанційного надання освітніх послуг створюють необхідність наукових досліджень в розрізі цього питання. На сучасному етапі повномасштабного впровадження дистанційної освіти можемо констатувати, що особливі характеристики дистанційної форми навчання (мінімізовані й 
опосередковані функції педагога-наставника, більший ступінь самоорганізації студентів, важливість їхньої самомотивації та раціонального таймменеджменту) створюють передумови задля відповідного виховного впливу. Разом із тим, виховне навантаження дистанційної освіти має бути узгодженим 3 основоположними принципами виховної роботи у вищому навчальному закладі. Насамперед таку відповідність ми вбачаємо в інтенсифікації методів самоосвіти та самостійної роботи. Повсякчасне використання сучасних освітніх платформ, часто у гейміфікованому форматі, сприяють підвищенню мотивації студентів, яка згодом трансформується в самомотивацію. Разом із тим, віддалений формат роботи у сукупності 3 правильно підібраними навчальними завданнями (створення інтелект-карт, робота над індивідуальними і груповими проектами, презентаціями, колажами, вирішення відкритих проблемних питань тощо) здатні активізувати інформаційно-пошукову складову навчального процесу, а також слугують фундаментом для розвитку креативності студентів. У свою чергу, зазначене сприяє розвитку навичок самоосвіти, що відповідає головному освітньому принципу: освіта протягом життя. В означеному контексті нами було виокремлено відповідні рівні виховного потенціалу дистанційної освіти: мотиваційний, інформаційно-пошуковий, організаційний, креативний та рівень самоосвіти. Перспективу подальших розвідок вбачаємо в розробленні й апробації методики виховного впливу під час дистанційно організованого навчання у вищій школі.

\section{Лimepamypa:}

1. Дубасенюк О. Концептуальні положення теорії професійної виховної діяльності педагога. Педагогіка і психологія. 1999. № 4. С. 91.

2. Дурманенко О. Виховна робота ВНЗ як чинник формування особистості майбутнього фахівця. Науковий вісник Східноєвропейського національного університету імені Лесі Українки. Серія: Педагогічні науки. 2016. №2 (304). С. 31-37.

3. Кухаренко В., Бондаренко В. Екстрене дистанційне навчання в Україні. Колективна монографія. Харків 2020. 411c. URL: https://duan.edu.ua/images/News/UA/Departments/ Management/2020/monograph_ekstr_dyst_navch.pdf

4. Лялюк О., Лялюк А., Поліщук О. Використання студентами методів тайм-менеджменту під час самостійного навчання в університеті. Педагогіка безпеки. 2020. № 1(5). С. 18-25.

5. Найдьонов I. Найважливіша педагогічна проблема сучасного менеджменту дистанційної освіти. Наукові перспективи. 2021. №5(11). С. 375-385.

6. Осаульчик О. Роль позааудиторної виховної роботи в контексті перебудови освітнього процесу вищих навчальних закладів. Наукові записки Вінницького державного педагогічного університету імені Михайла Коиюбинського. Серія: Педагогіка і психологія. 2012. № 36. С. 120-123.

7. Сопівник Р. Зміна підходів до навчання та виховання студентської молоді у вітчизняних вищих навчальних закладах України (кінця XX-поч. XXI ст.). Історичні записки. 2008. Випуск 20. URL: http://politics.ellib.org.ua/pages-4893.html

8. Фіцула М. Педагогіка вищої школи. Київ. 2006. 352 с.

9. Ivanytska, N., Tymoshchuk, N., Dovhan, L., Osaulchyk, O., Havryliuk, N. (2021). Effectiveness of digital resources in the learning management system within online education of future entrepreneurs. Journal of Entrepreneurship Education, 24(4). URL:https://www.abacademies.org/ 
articles/effectiveness-of-digital-resources-in-the-learning-management-system-within-online-education-offuture-entrepreneurs-10533.html

\section{References:}

1. Dubaseniuk, O. (1999). Kontseptualni polozhennia teorii profesiinoi vykhovnoi diialnosti pedahoha [Conceptual provisions of the theory of professional educational activity of a teacher]. Pedahohika i psykholohiia (4). 91-95 [in Ukrainian].

2. Durmanenko, O. (2016). Vykhovna robota VNZ yak chynnyk formuvannia osobystosti maibutnoho fakhivtsia [University educational work as a factor in forming the personality of the future specialist]. Naukovyi visnyk Skhidnoievropeiskoho natsionalnoho universytetu imeni Lesi Ukrainky. Seriia: Pedahohichni nauky 2(304). 31-37[in Ukrainian].

3. Kukharenko, V., Bondarenko, V. (2020). Ekstrene dystantsiine navchannia v Ukraini [Emergency distance learning in Ukraine]. Kolektyvna monohrafiia. 411s. Retrieved from https://duan.edu.ua/images/ News/UA/Departments/Management/2020/monograph_ekstr_dyst_navch.pdf [in Ukrainian].

4. Lialiuk, O., Lialiuk, A., Polishchuk, O. (2020). Vykorystannia studentamy metodiv taimmenedzhmentu pid chas samostiinoho navchannia $\mathrm{v}$ universyteti [The usage of time management methods by students during independent study at the university]. Pedahohika bezpeky. 1(5). 18-25 [in Ukrainian].

5. Naidonov, I. (2021). Naivazhlyvisha pedahohichna problema suchasnoho menedzhmentu dystantsiinoi osvity [The most important pedagogical problem of modern distance education management]. Naukovi perspektyvy 5(11). 375-385 [in Ukrainian].

6. Osaulchyk, O. (2012). Rol pozaaudytornoi vykhovnoi roboty v konteksti perebudovy osvitnoho protsesu vyshchykh navchalnykh zakladiv [The role of extracurricular educational work in the context of restructuring the educational process of higher education institutions]. Naukovi zapysky Vinnytskoho derzhavnoho pedahohichnoho universytetu imeni Mykhaila Kotsiubynskoho. Seriia: Pedahohika $i$ psykholohiia 36. 120-123 [in Ukrainian].

7. Sopivnyk, R. (2008). Zmina pidkhodiv do navchannia ta vykhovannia studentskoi molodi u vitchyznianykh vyshchykh navchalnykh zakladakh Ukrainy (kintsia KhKh-poch. KhKhI st.) [Changing approaches to teaching and educating students in higher educational institutions of Ukraine (late XX-early XXI century)] Istorychni zapysky (20). Retrieved from http://politics.ellib.org.ua/pages-4893.html [in Ukrainian].

8. Fitsula, M. (2006). Pedahohika vyshchoi shkoly [Pedagogy of high school]. 352 s. [in Ukrainian].

9. Ivanytska, N., Tymoshchuk, N., Dovhan, L., Osaulchyk, O., Havryliuk, N. (2021). Effectiveness of digital resources in the learning management system within online education of future entrepreneurs. Journal of Entrepreneurship Education, 24(4). Retrieved from https://www.abacademies.org/ articles/effectiveness-of-digital-resources-in-the-learning-management-system-within-online-educationof-future-entrepreneurs-10533.html [in English]. 